\title{
A Comparative Study on Nutritional Analysis of Proximate Composition and Total Mineral Contents of Different Varieties of Pearl Millet
}

\author{
Renuka Jandu* and Asha Kawatra \\ Department of Foods and Nutrition, I.C. College of Home Science, CCS Haryana Agricultural \\ University, Hisar, Haryana, India \\ *Corresponding author
}

\section{A B S T R A C T}

\section{Keywords}

Pearl millet, Biofortified, Proximate composition, Mineral

Article Info

Accepted:

15 May 2019

Available Online:

10 June 2019
The present study was undertaken to study the nutritional composition of different varieties pearl millet. The nutritional evaluation indicated that the moisture content of pearl millet varieties HC-20 (bio-fortified), HHB-67 (improved) and WHC-901 was $7.41,8.61$ and 7.89 per cent, respectively. The protein content of HC-20 (biofortified), HHB-67 improved and WHC-901 were $11.95 \mathrm{~g} / 100 \mathrm{~g}, 12.48 \mathrm{~g} / 100 \mathrm{~g}$ and $11.81 \mathrm{~g} / 100 \mathrm{~g}$, respectively. The crude fibre was higher (1.67\%) in HHB-67 (improved) variety. Total mineral content in selected pearl millet varieties indicated that, highest iron $(7.23 \mathrm{mg} / 100 \mathrm{~g})$ and zinc $(4.35 \mathrm{mg} / 100 \mathrm{~g})$ contents were found in pearl millet variety HC-20 (bio-fortified) and highest calcium content $(54.87 \mathrm{mg} / 100 \mathrm{~g}$ ) was found in variety HHB-67 (improved).

\section{Introduction}

Millets are a group of small seeded species of cereal crops, widely grown around the world for food and fodder. The word 'mil' refers to thousands of grains that can be held in a handful. Millets are also called as small, coarse or minor millets. Pearl millet (Pennisetum typhoides), cultivated mostly in semi-arid parts of Africa and Asia, is major source of energy and proteins. It is also known as poor man's grain, which happens to have high nutritional quality. Pearl millet is the sixth most grown cereal in the world (FAO, 2011). It contributes to food security in the arid region. The nutritive content of pearl millet is equivalent or even superior to those of other cereals (Obizoba et al., 1994). Nutritionally, pearl millet makes an important contribution to human diet due to high levels of calcium, iron, zinc, lipids and high quality proteins. Carbohydrates are the major component of pearl millet grains varying from 71.82 to 81.02 per cent (Cheik et al., 2006). Pearl millet usually has higher protein and fat content than sorghum or the other millets because the kernel is a naked caryopsis. Its protein content is not only high but also of good quality except for lysine deficiency (Gill, 1991). Protein and fat content of pearl 
millet varieties vary from 12.25 to 13.09 per cent and 4.32 to 5.11 per cent, respectively (Abdalla et al., 2009) and protein digestibility ranges from 47.30 to 61.17 per cent (Anju, 2005). The total sugars in pearl millet ranges from 2.55 to 2.93 per cent, non-reducing sugars ranges from 2.15 to 2.57 per cent and reducing sugars from 0.34 to 0.39 per cent (Rekha, 1997 and Poonam, 2002). In India, almost $46 \%$ of the grain production of pearl millet goes for human food use, $37.5 \%$ for cattle feed, $7.7 \%$ for poultry feed $8.8 \%$ for alcohol industry and only a small fraction $(0.4 \%)$ is used for seed purpose. Compared to the availability of ready-to-eat products from rice, wheat and corn, the products based on minor cereals such as sorghum and pearl millet are still scanty. Sorghum and pearl millet possess unique nutritional characteristics, specifically, they are glutenfree, represent good source of carbohydrates, rich in dietary fibre, phenolic compounds and also minerals (Saturni et al., 2010).

\section{Materials and Methods}

This study was carried out in Department of Foods and Nutrition, I.C College of Home Science, Chaudhary Charan Singh Haryana Agricultural University, Hisar.

\section{Procurement of material}

Three varieties of pearl millet viz. Biofortified (HC-20), white (WHC-901) and Grey (HHB-67 improved) were procured from Bajra section, Department of Genetics and Plant Breeding, CCS Haryana Agricultural University, Hisar.

\section{Nutritional evaluation of various varieties of pearl millet}

Moisture, crude protein, crude fat, crude fiber and ash were estimated by employing the standard methods of analysis (AOAC, 2012).
Iron and zinc in acid digested samples were determined by Atomic Absorption Spectrophotometer according to the method (Lindsey and Norwell, 1969). Total calcium was determined calorimetrically by the method (Chopra and Kanwar, 1979).

\section{Results and Discussion}

\section{Nutritional evaluation of various pearl millet varieties}

\section{Proximate composition}

The data in respect of proximate composition of selected pearl millet varieties are presented in Table 1.

The moisture content of pearl millet varieties HC-20, HHB-67 improved and WHC-901 was $7.41,8.61$ and $7.89 \mathrm{~g} / 100 \mathrm{~g}$, respectively. The crude protein content was $11.95,12.48$ and $11.81 \mathrm{~g} / 100 \mathrm{~g}$ in HC-20, HHB-67 improved and WHC-901, respectively. The crude protein content of HHB-67 improved was significantly $(\mathrm{P}<0.05)$ higher than both varieties of pearl millet HC-20 and WHC901.

The crude fat content was observed to be significantly $(\mathrm{P}<0.05)$ higher in WHC901(6.19 g/100g) followed by HC-20 (6.10 $\mathrm{g} / 100 \mathrm{~g})$ and HHB-67 improved (5.44 g/100g), respectively. Pearl millet variety $\mathrm{HC}-20$ had highest ash content $1.92 \mathrm{~g} / 100 \mathrm{~g}$. The crude fibre content of pearl millet varieties HC-20, HHB-67 improved and WHC-901 were 1.28, 1.67 and $1.27 \mathrm{~g} / 100 \mathrm{~g}$, respectively. The crude fibre of HHB-67 improved was significantly higher than that of other varieties.

\section{Total minerals}

The results of total calcium, iron and zinc contents of pearl millet varieties are presented in Table 2. 
The total calcium content of pearl millet varieties HC-20, HHB-67 improved and WHC-901 was observed to be $51.79,54.87$ and $50.91 \mathrm{mg} / 100 \mathrm{~g}$, respectively. The total calcium content differed significantly $(\mathrm{P}<0.05)$ among pearl millet varieties.

The iron and zinc content of pearl millet variety $\mathrm{HC}-20$ was $7.23 \mathrm{mg} / 100 \mathrm{~g}$ and 4.35 $\mathrm{mg} / 100 \mathrm{~g}$, respectively, which were significantly higher than other varieties.

The moisture content of pearl millet varieties HC-20, HHB-67 improved and WHC-901 was $7.41,8.61$ and $7.89 \mathrm{~g} / 100 \mathrm{~g}$, respectively. Chiek et al., (2006) also reported similar values for different pearl millet varieties.
Sehgal and Kawatra (2002) and Anju (2005) also reported a wide range of moisture content for different pearl millet varieties. Modu et al., (2005) reported higher moisture content i.e. 10.09 to $11.09 \mathrm{~g} / 100 \mathrm{~g}$ in different pearl millet varieties.

The data shows that crude protein content of HHB-67 improved was significantly higher than both HC-20 and WHC-901. The crude protein content was $11.95,12.48$ and 11.81 $\mathrm{g} / 100 \mathrm{~g}$ in HC-20, HHB-67 improved and WHC-901, respectively. Almost similar results in respect to protein content have been reported by Modu et al., (2005). Who also found protein content of pearl millet cultivars in range of 10.73 to $12.97 \mathrm{~g} / 100 \mathrm{~g}$.

Table.1 Proximate composition of selected pearl millet varieties (g/100g, on dry matter basis)

\begin{tabular}{|l|l|l|l|l|l|}
\hline Variety & Moisture & $\begin{array}{l}\text { Crude } \\
\text { protein }\end{array}$ & $\begin{array}{l}\text { Crude } \\
\text { Fat }\end{array}$ & Ash & $\begin{array}{l}\text { Crude } \\
\text { fibre }\end{array}$ \\
\hline HC-20 & $7.41 \pm 0.08$ & $11.95 \pm 0.05$ & $6.10 \pm 0.16$ & $1.92 \pm 0.10$ & $1.28 \pm 0.04$ \\
\hline HHB-67 improved & $8.61 \pm 0.14$ & $12.48 \pm 0.28$ & $5.44 \pm 0.12$ & $1.79 \pm 0.03$ & $1.67 \pm 0.03$ \\
\hline WHC-901 & $7.89 \pm 0.39$ & $11.81 \pm 0.14$ & $6.19 \pm 0.21$ & $1.88 \pm 0.06$ & $1.27 \pm 0.04$ \\
\hline CD(P<0.05) & 0.83 & 0.62 & 0.58 & 0.23 & 0.14 \\
\hline
\end{tabular}

Values are mean $\pm \mathrm{SE}$ of three independent determinations

Significant at 5\% level

Table.2 Total mineral contents in selected pearl millet varieties (mg/100g, on dry matter basis)

\begin{tabular}{|l|l|l|l|}
\hline Variety & Calcium & Iron & Zinc \\
\hline HC-20 & $51.79 \pm 0.59$ & $7.23 \pm 0.35$ & $4.35 \pm 0.47$ \\
\hline HHB-67 improved & $54.87 \pm 0.37$ & $6.41 \pm 0.03$ & $3.16 \pm 0.05$ \\
\hline WHC-901 & $50.91 \pm 0.55$ & $6.89 \pm 0.35$ & $2.92 \pm 0.05$ \\
\hline CD(P<0.05) & 1.76 & 0.78 & 0.95 \\
\hline
\end{tabular}

Values are mean $\pm \mathrm{SE}$ of three independent determinations

Significant at $5 \%$ level

Among three varieties of pearl millet studied the crude fat content was observed to be highest in WHC-901(6.19 g/100g) followed by HC-20 $(6.10 \mathrm{~g} / 100 \mathrm{~g})$ and HHB-67 improved $(5.44 \mathrm{~g} / 100 \mathrm{~g})$, respectively. Results of present study are in agreement within findings of Anju (2005) earlier study who reported fat content for different pearl millet in range of 5.03 to $6.31 \mathrm{~g} / 100 \mathrm{~g}$.

The ash content of HC-20 (1.92 g/100g) was highest followed by WHC-901 $(1.88 \mathrm{~g} / 100 \mathrm{~g})$ and then HHB-67 improved $(1.79 \mathrm{~g} / 100 \mathrm{~g})$. Variable amount of ash was reported in pearl 
millet which may be due to varietal difference and also variation agro climatic condition. Modu et al., (2005) found ash content in range of $1.20-1.53 \mathrm{~g} / 100 \mathrm{~g}$. Varsha (2003) reported ash content of pearl millet as 2.64 $\mathrm{g} / 100 \mathrm{~g}$. The crude fibre content of pearl millet varieties HC-20, HHB-67 improved and WHC-901 was 1.28, 1.67 and $1.27 \mathrm{~g} / 100 \mathrm{~g}$, respectively. Mamta (2015) reported fiber content as 1.71 to $1.98 \mathrm{~g} / 100 \mathrm{~g}$. The values of crude fibre content reported in the present study are also close to $1.96 \mathrm{~g} / 100 \mathrm{~g}$ earlier reported by Fasasi (2009).

The total calcium content of pearl millet varieties HC-20, HHB-67 improved and WHC-901 was observed to be $51.79,54.87$ and $50.91 \mathrm{mg} / 100 \mathrm{~g}$, respectively. Almost similar range of calcium content (46.0- 68.0 $\mathrm{mg} / 100 \mathrm{~g}$ ) in different pearl millet varieties has been observed by Anju (2005).

The iron content of HC-20, HHB-67 improved and WHC-901 was observed 7.23, 6.41 and $6.89 \mathrm{mg} / 100 \mathrm{~g}$, respectively (Table $2)$. The iron content of bio-fortified variety (HC-20) of pearl millet was highest than other varieties of pearl millet. Abdalla et al., (1998) reported the total iron content ranging from 7.0 to $18.0 \mathrm{mg} / 100 \mathrm{~g}$ in pearl millet varieties.

The zinc content of bio-fortified variety (HC20) $(4.35 \mathrm{mg} / 100 \mathrm{~g})$ of pearl millet was observed higher than that present in other two varieties HHB-67 improved (3.16 mg/100g) and WHC-901 (2.92). These results are comparable to the value reported earlier as $4.23-7.38 \mathrm{mg} / 100 \mathrm{~g}$ and $4.12-5.20 \mathrm{mg} / 100 \mathrm{~g}$ by Anju (2005) and Nithya et al., (2006), respectively.

\section{References}

Abdalla, A.A., Ahmed, U.H., Ahmed, A.R., El-Tinay, A.H. and Ibrahim, K.A. 2009. Physiochemical characterization of traditionally extracted pearl millet starches. J. Applied Sci. Res. 5 (11): 2016-2027.

Abdalla, A.A., Tinay, A.H., Mohamed, B.E., Abdalla and A.H. 1998. Proximate composition, starch, phytate and mineral contents of ten pearl millet genotypes. Food Chem. 63 (2): 243246.

Anju. 2005. Nutritional evaluation and product development from white and yellow pearl millet varieties. M.Sc. Thesis, CCSHAU, Hisar, India.

AOAC. 2000. Official Methods of Analysis. Association of Official. Analytical Chemists, Washington, D.C. USA.

Cheik, Q.A.T., Aly, S., Yaya, B. and Alfred, ST. 2006. A comparative study on nutritional and technological quality of fourteen (14) cultivars of pearl millet (Pennisetum glaucum (L.) Leeke) in Burkina Faso.

Chopra, S.L. and Kanwar, J.S., 1979. Analytical Agricultural Chemist, $4^{\text {th }}$ edition, Kalyani Publisher, New Delhi.

FAO, 2011. www.faostat.org. Production: crop-pulses

FAO. 2011. Production Year Book

Fasasi, O.S. 2009. Proximate, antinutritional factors and functional properties of processed pearl millet (Pennisetum glaucum). J. Food Sec. Techol. 7 (3): 92-97.

Gill, K. S. 1991. Pearl millet and its improvement. Publications and Information Division, ICAR, New Delhi. pp 1-7.

Lindsey, W.L. and Norwell, M.A. 1969. A new DPTA-TEA soil test for zinc and iron. Agron. Abst. 61:84-89.

Mamta (2015) Development and nutritional evaluation of pearl millet (Pennisetum glaucum) based convenience foods. Ph.d Thesis, CCSHAU, Hisar, India.

Modu, Laminu, S.H.H. and Nkama, I. 2005. Production, chemical and sensory 
properties of ogi from different pearl millet varieties. J. Biological Sci. 5 (2): 103-106.

Nithya, K.S., Ramachandramurty, B., Krishnamoorthy, V.V. 2006. Assessment of antinutritional factors, mineral and enzyme activities of the traditional (Co7) and hybrid (Cohcu-B) pearl millet (Pemnisetum glaucum) as influenced by different processing methods. J. Applied Sci. Res. 2 (12): 1164-1168.

Obizoba, I. C. and Atti, J.V. 1994. Evaluation of the effect of processing techniques on the nutrient and antinutrient contents of pearl millet (Pennisetum glaucum) $\mathrm{Pl}$. Food Hum. Nutr. 45: 2324.

Poonam. 2002. Effect of acid and heat treatment on nutrient composition and shelf life of pearl millet (Pennisetum glaucum) flour. M. Sc. Thesis, CCSHAU, Hisar, India.

Rekha. 1997. Efficacy of processing techniques in the utilization of pearl millet for value- added products. M. Sc. Thesis, CCSHAU, Hisar, India.

Saturni, L., Ferretti, G. and Bacchetti, T. 2010. The gluten-free diet: Safety and nutritional quality. Nutri. 2(1): 16-34.

Sehgal, S. and Kawatra, A. 2002. Processing of millets for value addition and development of health foods (NATPRNPS-I).

Varsha. 2003. Nutritional evaluation of utilization of selected cereals and pulses for value addition of wheat based products. M.Sc. Thesis, CCSHAU, Hisar, India

\section{How to cite this article:}

Renuka Jandu and Asha Kawatra. 2019. A Comparative Study on Nutritional Analysis of Proximate Composition and Total Mineral Contents of Different Varieties of Pearl Millet. Int.J.Curr.Microbiol.App.Sci. 8(06): 1868-1872. doi: https://doi.org/10.20546/ijcmas.2019.806.223 